\title{
Eosinophilic Ascites: Singular Presentation of Eosinophilic Gastrointestinal Disorder
}

Letrán $\mathrm{A}^{1}$, Hueso $\mathrm{S}^{2}$, González $\mathrm{V}^{2}$, Ramos $\mathrm{C}^{3}$, Amaya $\mathrm{A}^{4}$

${ }^{1}$ Allergy Unit, Hospital HLA Jerez Puerta del Sur, Jerez de la Frontera, Spain

${ }^{2}$ Internal Medicine Unit, Hospital HLA Jerez Puerta del Sur, Jerez de la Frontera, Spain

${ }^{3}$ Pathology Unit, Hospital HLA Jerez Puerta del Sur, Jerez de la Frontera, Spain

${ }^{4}$ Digestive Unit, Hospital HLA Jerez Puerta del Sur, Jerez de la Frontera, Spain

J Investig Allergol Clin Immunol 2018; Vol. 28(4): 275-276 doi: $10.18176 /$ jiaci.0260

Key words: Eosinophilic ascites. Eosinophilic gastroenteritis. Eosinophils. Food allergy.

Palabras clave: Ascitis eosinofílica. Gastroenteritis eosinofílica. Eosinófilo. Alergia alimentaria.

Primary eosinophilic gastrointestinal disorders (EGID) are characterized by abnormal accumulation of eosinophils in the gastrointestinal tract in the absence of secondary causes of eosinophilia and mainly include eosinophilic esophagitis (EoE) and eosinophilic gastroenteritis (EGE) [1]. In EoE, the eosinophilic infiltrate is limited to the esophagus, but in EGE, any gastrointestinal segment might be involved, with the stomach and duodenum being the most commonly affected sites [2]. Eosinophilic ascites (EA) is an unusual presentation of EGE, occurring when there is serosal involvement of the affected section of the bowel $[3,4]$.

A 36-year-old white man with a history of obesity, hypertension, and allergic rhinitis and asthma caused by sensitization to house dust mites came to the emergency department with a 4-week history of epigastric pain, abdominal distention, nausea, and vomiting. Omeprazole $40 \mathrm{mg} / \mathrm{d}$ was ineffective. He denied difficulty eating, heartburn, choking, dysphagia, regurgitation, or food impaction. He presented distended abdomen with active bowel sounds and ascites. Hepatomegaly, splenomegaly, and abdominal mass were ruled out. Urgent abdominal ultrasonography confirmed these clinical signs but ruled out portal hypertension. A complete blood count revealed an increase in the white cell count (15 $340 \mathrm{~m} / \mathrm{L}$ with $32 \%$ eosinophils [ $4940 \mathrm{~m} / \mathrm{L}]$ ), elevated erythrocyte sedimentation rate $(16 \mathrm{~mm} / \mathrm{h})$, and normal results in the liver and renal function tests. Tumor markers, tryptase, antineutrophil cytoplasmic antibodies, celiac serology, and digestive parasites were normal during admission. Serology for human immunodeficiency virus, hepatitis B and C viruses, and Echinococcus granulosus was negative. The test for detection of Helicobacter pylori was also negative. Serum IgE was elevated (1832 kU/L). Specific IgE values for Dermatophagoides pteronyssinus, wheat, and grass pollen (Phleum pratense) were, respectively $1.07 \mathrm{kU} / \mathrm{L}, 6.03 \mathrm{kU} / \mathrm{L}$, 
and $<0.10 \mathrm{kU} / \mathrm{L}$. Results were negative for egg white/yolk, milk, legumes, fish, seafood, nuts, flours, and Anisakis simplex. The skin prick test was only positive to house dust mites (D pteronyssinus, $7 \times 7 \mathrm{~mm}$; and Dermatophagoides farinae, $4 \times 4 \mathrm{~mm})$. Prick-by-prick tests with egg white/yolk, milk, legumes, fish, seafood, nuts, and flours were only positive to wheat flour $(5 \times 5 \mathrm{~mm})$. A thoracic-abdominalpelvic computed tomography scan showed a moderate amount of pelvic free fluid, which was identified as moderate ascites without lymphadenopathies. A small right pleural effusion was also detected. Ultrasound-guided abdominal paracentesis revealed hematic fluid (total protein, $5.50 \mathrm{~g} / \mathrm{dL}$; lactate dehydrogenase, $158 \mathrm{mg} / \mathrm{dL}$; adenosine deaminase, $0.20 \mathrm{U} / \mathrm{L}$; white blood cells, $9100 / \mathrm{mL}$ [45\% eosinophils]). No cytological signs of malignancy were detected. Laboratory testing of the ascites fluid for bacterial culture and tuberculosis was negative. After 5 weeks of treatment with proton pump inhibitors, upper gastrointestinal endoscopy up to the second part of duodenum did not reveal macroscopic anomalies. Histopathology showed heavy infiltration of eosinophils corresponding to esophageal epithelium ( 35 cells/HPF); stomach and duodenum biopsies (deep lamina propria) demonstrated nonspecific acute lymphocytic inflammation with eosinophils (40 cells/HPF). With a high suspicion of EA, we started the patient on oral prednisone $(60 \mathrm{mg} /$ day $)$ and a diet excluding wheat. Symptoms resolved rapidly after a few days, the blood eosinophil count $(1800 \mathrm{~m} / \mathrm{L})$ decreased, and the abdominal fluid gradually disappeared (confirmed by ultrasonography). Oral corticosteroids were maintained for 2 weeks and then tapered. The patient was recommended to continue with the wheat-free diet. After 4 months of follow-up under the same diet, the patient was clinically asymptomatic without medication, and his abdominal scan was normal.

We report the case of a young adult atopic patient in whom clinical presentation and histopathological findings confirmed EGE and EA, as previously described [5]. In 1970, Klein et al [6] divided the most common EGE classification into 3 different patterns, namely, the mucosal, muscular, and serosal patterns. The serosal pattern is the rarest of the three and is regarded as the special feature of this pattern. It is considered clinically distinct in that it is characterized by abdominal bloating, high eosinophil count, favorable response to corticosteroids [6], and pleural effusion [7]. All of these characteristics were present in the case we report. Although serosal involvement could not be confirmed by the pathologist, we do not reject the diagnosis. The classification of Klein et al is considered by many authors to be inaccurate, because the layers involved are still not easy to find in daily clinical practice. Only mucosal and submucosal biopsies were taken in almost all cases, and in EGE, clinical and pathologic features often overlap [4]. Fifty percent of patients with EGE have a history of allergy [8]. Nevertheless, IgE antibodies are rarely directed against identified food allergens. A limitation of our study is the simultaneous indication of 2 treatment modalities, which prevents us from knowing which was more effective in the resolution of symptoms. However, given the moderate degree of sensitization and its key role in dietary treatments in other eosinophilic gastrointestinal diseases (eg, eosinophilic esophagitis) [9], we considered wheat to be the potential initial trigger of EGE and EA and therefore recommended avoidance.

\section{Funding}

The authors declare that no funding was received for the present study.

\section{Conflicts of Interest}

The authors declare that they have no conflicts of interest.

\section{References}

1. Travers J, Rothemberg ME. Eosinophils in mucosal immune responses. Mucosal Immunol. 2015;8(3):464-75.

2. Zang M, Li Y. Eosinophilic gastroenteritis: A state-of-the-art review. J Gastroenterol Hepatol. 2017;32(1):64-72.

3. Rodríguez B, Domínguez J, González JM, Kindelan C. Eosinophilic gastroenteritis due to allergy to cow's milk. J Investig Allergol Clin Immunol. 2011;21(2):150-2.

4. Sheikh RA, Prindiville TP, Pecha RE, Ruebner BH. Unusual presentation of eosinophilic gastroenteritis: case series and review of literature. World J Gastroenterol. 2009;15:2156-61.

5. Bleibel F, Fragoza K, Faller GT. Acute eosinophilic ascites in a middle-aged man. Case Rep Gastrointest Med. 2012;2012:896523

6. Klein NC, Hargrove RL, Sleisenger MH, Jeffries GH. Eosinophilic gastroenteritis. Medicine (Baltimore). 1970;49(4):299-319.

7. Durieu I, Nove-Josserand R, Cathebras P, Durand DV, Rousset $H$, Levrat R. Eosinophilic ascites. 2 new case reports. Rev Med Interne. 1992;13(6):446-8.

8. Talley NJ, Shorter RG, Phillips SF, Zinsmeister AR. Eosinophilic gastroenteritis: a clinicopathological study of patients with disease of the mucosa, muscle layer, and subserosal tissues. Gut. 1990;31(1):54-8.

9. Lucendo AJ, Molina-Infante J, Arias Á, von Arnim U, Bredenoord AJ, Bussmann C, et al. Guidelines on eosinophilic esophagitis: evidence-based statements and recommendations for diagnosis and management in children and adults. United European Gastroenterol J. 2017;5(3):335-58.

\section{- Manuscript received December 20, 2017; accepted for publication April 20, 2018.}

Antonio Letrán Camacho Allergy Unit Hospital HLA Jerez Puerta del Sur Avenida Puerta del Sur $s / n$

11408 Jerez de la Frontera, Spain E-mail: aletrancamacho@gmail.com 